\title{
AN OPERATIONAL MANAGEMENT MODEL FOR A COAL MINING PRODUCTION UNIT
}

\author{
R. Visser ${ }^{1}$ and S.J. Claasen ${ }^{2}$ \\ ${ }^{1}$ Sasol Infrachem, South Africa \\ rene.visser@sasol.com \\ ${ }^{2}$ Department of Industrial and Systems Engineering \\ University of Pretoria, South Africa \\ schalk.claasen@eng.up.ac.za
}

\begin{abstract}
The coal mining industry faces increased pressure for higher quality coal at lower cost and increased volumes. To satisfy these requirements the industry needs technically skilled first line supervisors with operational management skills. Most first line supervisors possess the necessary technical, but not the required operational management skills. Various operational management philosophies, describing world-class operational management practices exist; however, it is not possible to implement these philosophies as-is in a mining environment due to the various differences between manufacturing and mining. The solution is to provide an operational management model, adapted from these philosophies, to first line supervisors in the coal mining industry.
\end{abstract}

\section{OPSOMMING}

Die steenkoolmynbedryf ervaar groeiende druk van die mark vir hoër gehalte steenkool, laer koste en verhoogde volumes. Om hierdie behoefte te bevredig benodig die myn tegniesgeskoolde eerstelyntoesighouers met bedryfsbestuursvaardighede. Ongelukkig beskik die meeste toesighouers wel oor die nodige tegniese kennis, maar nie die nodige bedryfsbestuursvaardighede nie. Daar bestaan verskeie bedryfsbestuursfilosofieë wat wêreldklas bedryfsbestuurspraktyke omskryf. Dit is egter nie moontlik om die filisofieë net so in die mynbedryf te implimenteer nie a.g.v. die verskille tussen vervaardiging en mynbou. Die oplossing is om ' $\mathrm{n}$ bedryfsbestuurmodel wat op hierdie filosofieë geskoei is, aan eerstelyntoesighouers in die steenkoolbedryf te verskaf.

\footnotetext{
${ }^{1}$ This author was enrolled for the M Eng (Industrial Engineering) at the Department of Industrial and Systems Engineering, University of Pretoria
} 


\section{INTRODUCTION}

Coal mining companies need first line supervisors with excellent operational management skills in order to cope with increasing market demands. At present most of the supervisors are highly skilled technically, but do not have adequate operational management skills. Furthermore, the current operational management philosophies that are available for use by first line supervisors are not developed for direct application in a mining environment and are also aimed at implementation in companies as a whole, not in individual production units. This article describes the development of an operational management model for use by first line supervisors of coal mining production units, utilising elements from various operational management philosophies.

\subsection{Challenges to the first line supervisor}

In the competitive coal mining industry it is important for a mining company to be flexible, lean, and profit driven. Coal prices can vary quite substantially from time to time, placing enormous pressure on the bottom line. In order to stay profitable and to sustain profits over the long term, coal mining companies need to be able to adapt to continuous fluctuations in demand for coal and the quality of coal needed. This creates pressure on the mine to continuously improve and stay lean, but still produce coal that satisfies quality and demand requirements.

To be able to adapt quickly, the coal mining company must be focused and business orientated with the end goal of the company in mind - to make profit now and in the future. This implies that all the employees of the mining company must be working towards this common goal and must be able to adapt quickly to the changing environment of the coal market. Top management sets the strategic direction and middle management needs to implement specific actions to follow the strategy. Middle management and the first line supervisors therefore need to have the necessary skills to adapt quickly, make the necessary changes and then track progress continuously. The first line supervisors need to manage their production units on sound business principles, using current world-class management tools and techniques in order to continuously improve the business.

The current reality is that most first line supervisors of production units are highly skilled in the technical and operational aspects of running a coal mining unit, but lack in specialised operational management skills. First line supervisors are mostly not adequately equipped to deal with the changing and stretched demands placed on them. McManus[1] and Lindbeck and Snower[2] discuss the changes that the supervisor in a modern company faces as a result of changes in technology and hierarchical structures.

\subsection{Operational management philosophies}

There are many operational management philosophies that are used successfully in manufacturing companies, for example: lean manufacturing, total quality management, constraint management, BPR (business process re-engineering) etc. These management philosophies all incorporate specific principles, operating rules and techniques and problem solving methods. A very comprehensive information base is available on each management philosophy as numerous textbooks, articles, and case studies have been written on the subject 
matter. These management philosophies are mostly developed for use in manufacturing environments. The principles, techniques, guidelines and tools refer to factory environments with fixed workstations, the transformation of raw materials into final products and the distribution of these final products. The philosophies assume a company wide implementation and are more than just management tools - it is a total perspective of the way that business is done in the company.

It is important to understand that there are physical, logistical and management differences between a coal mining production unit and a manufacturing company. For example in a mining unit the physical environment presents certain boundaries and increased safety risks that is not normally found in a manufacturing plant. There are also many unique logistical challenges that face the maintenance team of a mining production unit. These are for example the physical environment in which maintenance must be done, the distance from a workshop and the physical size of the equipment to be maintained. The scale of operations of a mining production unit is smaller than that of a typical manufacturing unit, specifically if the number of personnel and the equipment and product diversity are compared.

\section{APPROACH}

A structured approach, depicted in figure 1, is followed in developing the mining operational management model (MOM).

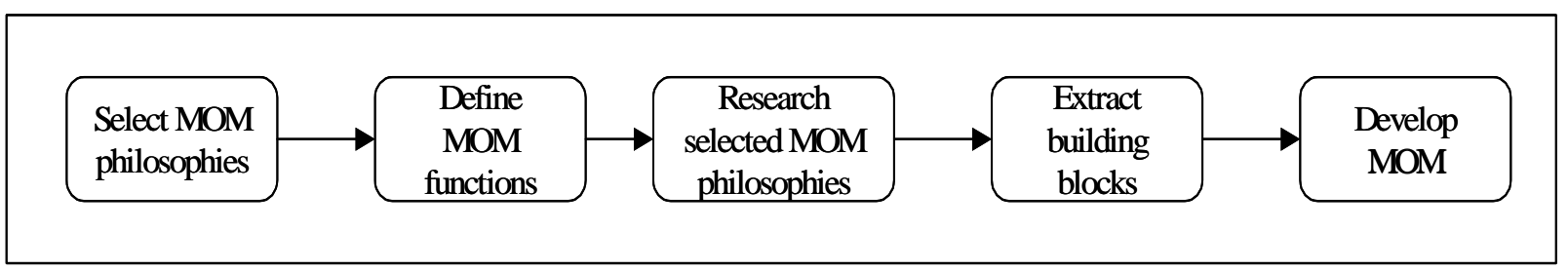

Figure 1: Structured development approach

\subsection{Selection of the operational management philosophies}

The operational management philosophies that are considered in the development of the mining operational management model are listed in table 1.

To determine which operational management philosophies to use, a set of criteria against which the philosophies can be measured, is defined.

The preferred operational management philosophy must:

- provide a solution that will facilitate continuous improvement and not necessarily quantum leap improvements

- be an original philosophy, not just a slight modification of an existing philosophy, or a combination of other philosophies

- be well documented in academic and business literature

- be well established - no brand-new or non-proven philosophies are considered

- cover a wide spectrum of the management of a company - therefore not only refer to one aspect such as, for example, maintenance management 


\begin{tabular}{|c|c|c|}
\hline $\begin{array}{l}\text { Lean } \\
\text { Manufacturing }\end{array}$ & $\begin{array}{l}\text { The essence of lean thinking is the elimination of muda } \\
\text { (waste) wherever it exists, within the individual firm but } \\
\text { also along the whole supply chain. }\end{array}$ & $\begin{array}{l}\text { The Antidote } \\
\text { Issue [3] }\end{array}$ \\
\hline $\begin{array}{l}\text { Total Quality } \\
\text { Management }\end{array}$ & $\begin{array}{l}\text { Total Quality Management is an interlocking arrangement } \\
\text { of procedures and practices that ensures that all } \\
\text { employees in every department are adequately trained } \\
\text { and directed to continuously implement aligned } \\
\text { improvements in quality, service and total cost such that } \\
\text { customer expectations are met or exceeded }\end{array}$ & $\begin{array}{l}\text { Bellefeuille } \\
\text { [4] }\end{array}$ \\
\hline Just-in-Time & $\begin{array}{l}\text { Just-in-Time is a philosophy that re-examines every } \\
\text { production step with the aim to eliminate every step that } \\
\text { is not absolutely necessary and does not directly add } \\
\text { value }\end{array}$ & Walter [5] \\
\hline 20 Keys & $\begin{array}{l}20 \text { Keys is the methodology for implementing PPORF } \\
\text { (practical program of revolution in factories). PPORF is a } \\
\text { simple improvement method with concrete and } \\
\text { systematic steps for drastically reforming and } \\
\text { strengthening every facet of the manufacturing } \\
\text { organisation. }\end{array}$ & Kobayashi [6] \\
\hline $\begin{array}{l}\text { Business } \\
\text { Process Re- } \\
\text { engineering }\end{array}$ & $\begin{array}{l}\text { BPR is the fundamental rethinking and radical design of } \\
\text { business processes to achieve dramatic improvements in } \\
\text { critical contemporary measures of performance such as } \\
\text { cost, quality, service and speed }\end{array}$ & $\begin{array}{l}\text { Zhang \& } \\
\text { Cao [7] }\end{array}$ \\
\hline $\begin{array}{l}\text { Management } \\
\text { by Objectives }\end{array}$ & $\begin{array}{l}\text { A system of management based on goal congruence as a } \\
\text { means of improving performance }\end{array}$ & $\begin{array}{l}\text { Dinesh \& } \\
\text { Palmer [8] }\end{array}$ \\
\hline $\begin{array}{l}\text { Total } \\
\text { Productive } \\
\text { Maintenance }\end{array}$ & $\begin{array}{l}\text { TPM is a scientific company-wide approach in which } \\
\text { every employee is concerned about the maintenance and } \\
\text { the quality and efficiency of his or her equipment. }\end{array}$ & Cooke [9] \\
\hline $\begin{array}{l}\text { Theory of } \\
\text { Constraints }\end{array}$ & $\begin{array}{l}\text { The Theory of Constraints is an overall management } \\
\text { approach which enables management to focus on the } \\
\text { identification and elimination of the organisation's } \\
\text { constraints and to implement a process of ongoing } \\
\text { improvement in order to achieve the organisation's goal }\end{array}$ & Geyser [10] \\
\hline
\end{tabular}

Table 1: List of possible operational management philosophies

Each management philosophy is matched against these criteria and evaluated on a scale of one (no alignment with criteria), two (average alignment with criteria) or three (full alignment with criteria). The results of the evaluation are given in table 2 .

The most applicable management philosophies in order of highest scores are Total Quality Management, Just-in-Time, Theory of Constraints, Lean Manufacturing and Business Process Re-engineering. The concepts of Lean Manufacturing are included in Just-in-Time, whilst Business Process Re-engineering is more appropriate when radical changes are required. The management philosophies Just-in-Time, Total Quality Management and Theory of Constraints, are therefore selected as a basis for developing the mining operational management model. 


\begin{tabular}{|l|c|}
\hline Management philosophy & Score \\
\hline Lean manufacturing & 14 \\
\hline Total quality management & 15 \\
\hline Just-in-time & 15 \\
\hline 20 keys & 9 \\
\hline Business Process Re-engineering & 13 \\
\hline Management by Objectives & 8 \\
\hline Total Productive Maintenance & 11 \\
\hline Theory of Constraints & 15 \\
\hline
\end{tabular}

Table 2: Evaluation of management philosophies

\subsection{Defining the functionality of the mining operational management model}

To extract those elements that will form the building blocks of the mining operational management model from Total Quality Management, Just-in-Time and Theory of Constraints, the functionality of the model is defined. For this purpose an objective matrix [11] (table 3) is constructed and the functions of the mining operational management model derived from it.

\begin{tabular}{|c|c|}
\hline Results to achieve & Results to prevent \\
\hline $\begin{array}{l}\text { - Identify problems } \\
\text { - Improve problem solving activities } \\
\text { - } \text { Breakdown silo’s between functions } \\
\text { - } \text { Assist unit leaders to become business } \\
\text { - } \text { orientated } \\
\text { - Reduce downtime } \\
\text { - } \text { Reduce cost } \\
\text { - } \quad \text { Streamline processes } \\
\text { Manage bottlenecks }\end{array}$ & $\begin{array}{l}\text { - } \quad \text { Complicated calculations } \\
\text { - } \text { Core paperwork } \\
\text { - } \quad \text { Saving cost to the detriment of total } \\
\text { - } \quad \text { Time consuction output } \\
\text { - Inflexible in use } \\
\text { - Short term focus only }\end{array}$ \\
\hline Available resources & Constraints \\
\hline $\begin{array}{l}\text { - } \quad \text { JIT, TQM, TOC information } \\
\text { - Extensive maintenance \& production } \\
\text { information (downtimes, rates etc) } \\
\text { - } \quad \text { Financial information }\end{array}$ & $\begin{array}{l}\text { - Resistance to change } \\
\text { - Employees of production unit not } \\
\text { trusting "another theoretical model” } \\
\text { - Attitudes and perceptions of supervisors } \\
\text { regarding "academic" sources }\end{array}$ \\
\hline
\end{tabular}

Table 3: Objective matrix for the mining model 
The functions of the mining model as derived from the objective matrix are:
A: Identify root causes
B: Provide solution frameworks
C: Manage cost expenditure
D: Increase throughput
E: Improve business orientation
F: Integrate sections
G: Streamline processes
$\mathrm{H}$ : Manage bottlenecks

An evaluation matrix [11] is used to determine which functions are most important to the first line supervisor. In the evaluation matrix each function is compared against all other functions. The results are depicted on a line graph (figure 2) - the functions "streamline processes", "manage bottlenecks" and "identify root causes" obtained the highest scores and are used to identify the building blocks for the mining operational management model from the selected management philosophies.

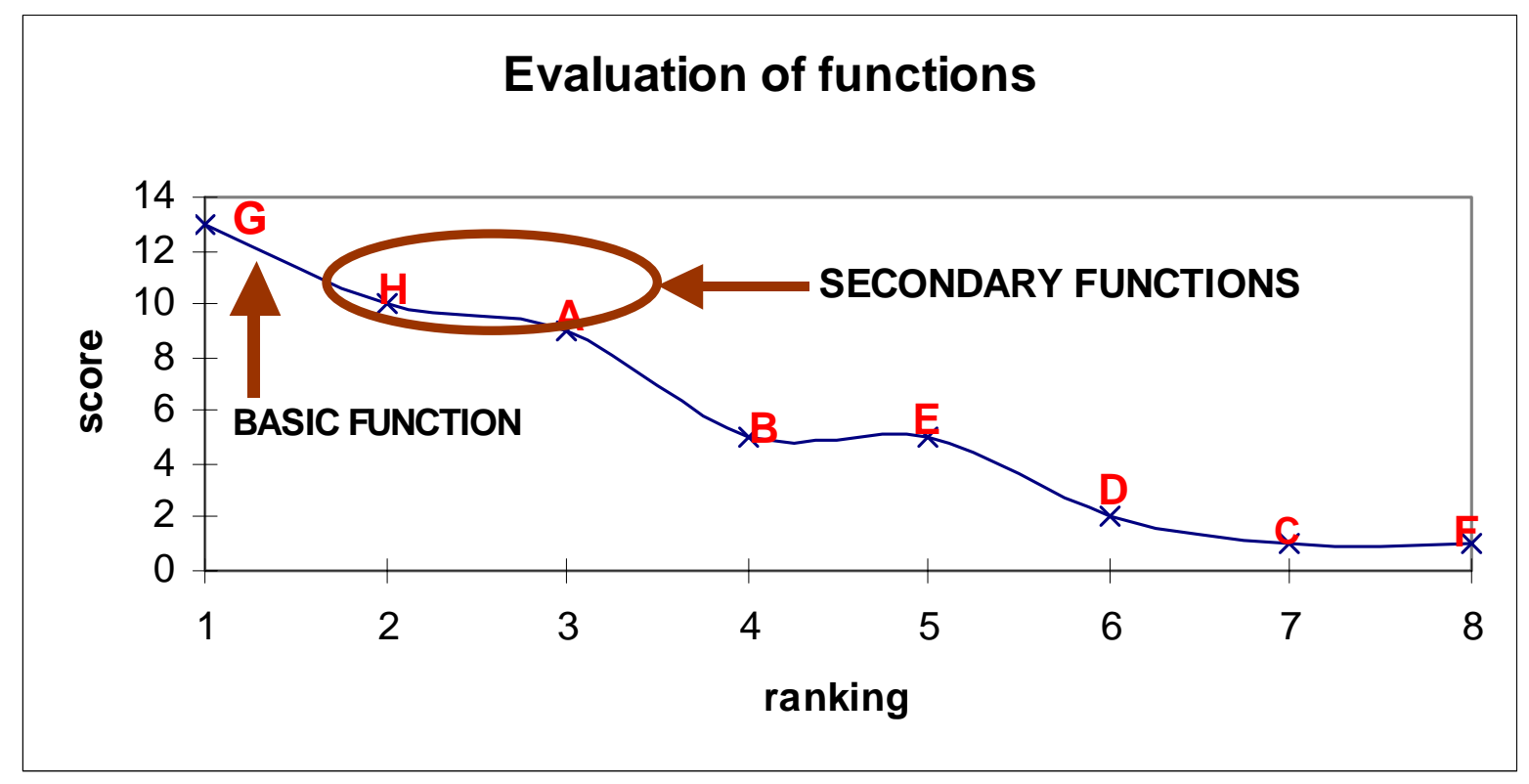

Figure 2: Function values

\subsection{Analysing the selected operational management philosophies}

In order to extract the model building blocks from the selected operational management philosophies the information needed is categorized as follows:

- Overall management philosophy (definition)

- The key values of the philosophy

- The impact on functions (functional activities / processes within a company)

- Problem solving tools and techniques

- Implementation pre-requisites 
The selected operational management philosophies are defined as follows:

Total Quality Management:

"An operational Management philosophy that aims to deliver a product that equals or exceeds the customer's expectations. This is achieved by designing quality in from the product development stage right through to the after sales service processes utilizing and involving everyone in the company"

Just-in-Time:

"An operational management philosophy that aims to deliver the required product, within very strict time limitations, to the exact requirements of the customer, without any waste present in the value chain."

Theory of Constraints:

"An operational management philosophy that manages the organisation as a chain and focuses on the weak links within the chain, with the aim to make profit now and in the future."

A summary of the information gleaned from the analysis is shown in table 4 .

\subsection{Evaluating the features of the selected operational management philosophies}

In order to identify the building blocks for the mining operational management model, the elements in table 4 are evaluated against the identified functions of the mining model (paragraph 2.2) by means of a perspective modeling matrix [11]. In a perspective modeling matrix each function is weighted proportionally based on the score from the evaluation matrix. Each element in table 4 is evaluated against each function, with the purpose to determine the extent of the impact that the element has on the function. The rating given is multiplied with the weight of the function, to determine a weighted rating. The weighted rating scores per element are summarized to lead to a total score per element.

After the evaluation of all elements per category (refer to table 4) the results are numerically and statistically analysed. From the analysis it is deduced that a set of 14 elements will fulfill the required functions of the mining operational management model. These 14 elements are listed in table 5.

\section{THE MINING OPERATIONAL MANAGEMENT MODEL}

For any production team to be successful it must define its purpose within the company. This definition should drive all decision-making in the unit. The production unit needs to define its vision and core values. Only then can the management of the unit be executed by means of the mining operational management model.

The model consists of two levels: a strategic and an operational level. The strategic level has a process focus and the continuous improvement of activities is driven from this level. On the 
operational level the focus is on the day-to-day running of the unit. There is a constant interchange of information between the two levels, and an integrated management approach is followed. The outline of the mining operational management model is illustrated in figure 3 and discussed in paragraphs 3.1 to 3.3. To indicate how the different elements from table 5 are utilised as building blocks, the element number is indicated in square brackets, i.e. [element $x]$.

\begin{tabular}{|c|c|c|}
\hline \multicolumn{3}{|c|}{ Key values } \\
\hline JIT & TQM & TOC \\
\hline $\begin{array}{ll}\text { - } & \text { Elimination of waste } \\
\text { - } & \text { Quality focus } \\
\text { - } & \text { imprinuous process } \\
\text { - } & \text { Total employee involvement }\end{array}$ & $\begin{array}{ll}\text { - } & \text { Total customer } \\
\text { satisfaction } \\
\text { - } & \text { Continuous } \\
\text { improvement } \\
\text { - } & \text { Fact based decision } \\
\text { making } \\
\text { - Total employee } \\
\text { involvement } \\
\end{array}$ & $\begin{array}{ll}\text { - } & \text { Causality \& necessity } \\
\text { - } & \text { Constraint management } \\
\text { - } & \text { Five steps for continuous } \\
\text { improvement } \\
\text { - } & \text { Constraint based } \\
\text { measurements }\end{array}$ \\
\hline \multicolumn{3}{|c|}{ Impact on functions } \\
\hline JIT & TQM & TOC \\
\hline $\begin{array}{ll}\text { Procurement \& Supply } \\
\text { Management } \\
\text { o Supplier management } \\
\text { o } \quad \text { Design \& development } \\
\text { o } \quad \text { Storage } \\
\text { - } \\
\text { Production \& scheduling } \\
\text { o } \quad \text { Group technology } \\
\text { o } \text { Model mixes } \\
\text { o } & \text { Reduced set-up times } \\
\text { o } & \text { Scheduling } \\
\text { o } & \text { Uniform work loads } \\
\text { o } & \text { Engineering } \\
\end{array}$ & $\begin{array}{ll}\text { - } & \text { Safety } \\
\text { - } & \text { Marketing } \\
\text { - } & \text { Product design } \\
\text { - } & \text { Procurement } \\
\text { - } & \text { In-bound \& out-bound } \\
& \text { logistics } \\
\text { - } & \text { Quality assurance } \\
\text { - } & \text { Organisational structure }\end{array}$ & $\begin{array}{ll}\text { - } & \text { Finance } \\
\text { - } & \text { Marketing \& sales } \\
\text { - } & \text { Scheduling } \\
\text { - } & \text { Project Management }\end{array}$ \\
\hline \multicolumn{3}{|c|}{ Problem solving tools and techniques } \\
\hline JIT & TQM & TOC \\
\hline $\begin{array}{l}\text { - Universal problem solving } \\
\text { sequence } \\
\text { - Specific measurements } \\
\text { o Value added efficiency } \\
\text { - Process improvement through } \\
\text { Statistical Process Control }\end{array}$ & $\begin{array}{l}\text { - } 14 \text { Quality control tools } \\
\text { - } 7 \text { Quality management } \\
\text { tools }\end{array}$ & $\begin{array}{l}\text { - Thinking processes } \\
\text { o Current reality tree } \\
\text { o Evaporating cloud } \\
\text { o Future reality tree } \\
\text { o Pre-requisite tree } \\
\text { o Transition tree } \\
\text { - Fundamental } \\
\text { measurements } \\
\text { o Throughput, inventory } \\
\text { and operating expense } \\
\text { - Control measurements } \\
\text { o Throughput-rand-days, } \\
\text { inventory-rand-days, } \\
\text { operating expense } \\
\end{array}$ \\
\hline
\end{tabular}

Table 4: Summary of features of selected operational philosophies 


\begin{tabular}{|c|l|l|l|}
\hline Nr & Element & Source & Category \\
\hline 1 & $\begin{array}{l}\text { Five focusing steps for continuous } \\
\text { improvement }\end{array}$ & TOC & Key values \\
\hline 2 & Continuous improvement & TQM & Key values \\
\hline 3 & Elimination of waste & JIT & Key values \\
\hline 4 & Five trees & TOC & Problem solving \\
\hline 5 & Universal problem solving sequence & JIT & Problem solving \\
\hline 6 & Constraints & TOC & Key values \\
\hline 7 & Total employee involvement & JIT & Key values \\
\hline 8 & Total employee involvement & TQM & Key values \\
\hline 9 & Organisational structure & TQM & Impact on functions \\
\hline 10 & Process improvement through SPC & JIT & Problem solving \\
\hline 11 & 14 Quality control tools & TQM & Problem solving \\
\hline 12 & Scheduling & TOC & Impact on functions \\
\hline 13 & Constraint based measurements & TOC & Key values \\
\hline 14 & Fact based decision making & TQM & Key values \\
\hline
\end{tabular}

Table 5: Building blocks for the mining operational management model

\subsection{Team focus: vision and core values}

The team vision must:

- be aligned with the company's vision

- refer to the quality of the product (coal)

- refer to the achievement of the throughput targets

The core values must as a minimum refer to the following:

- The company's core values

- Waste elimination being a passion [element 3]

- Constraints dictating all decisions [element 6]

- Decision making based on facts not emotions [element 14]

- The accountability and responsibility of all team members [elements 7 and 8] 


\section{STRATEGIC LEVEL : PROCESS FOCUS}

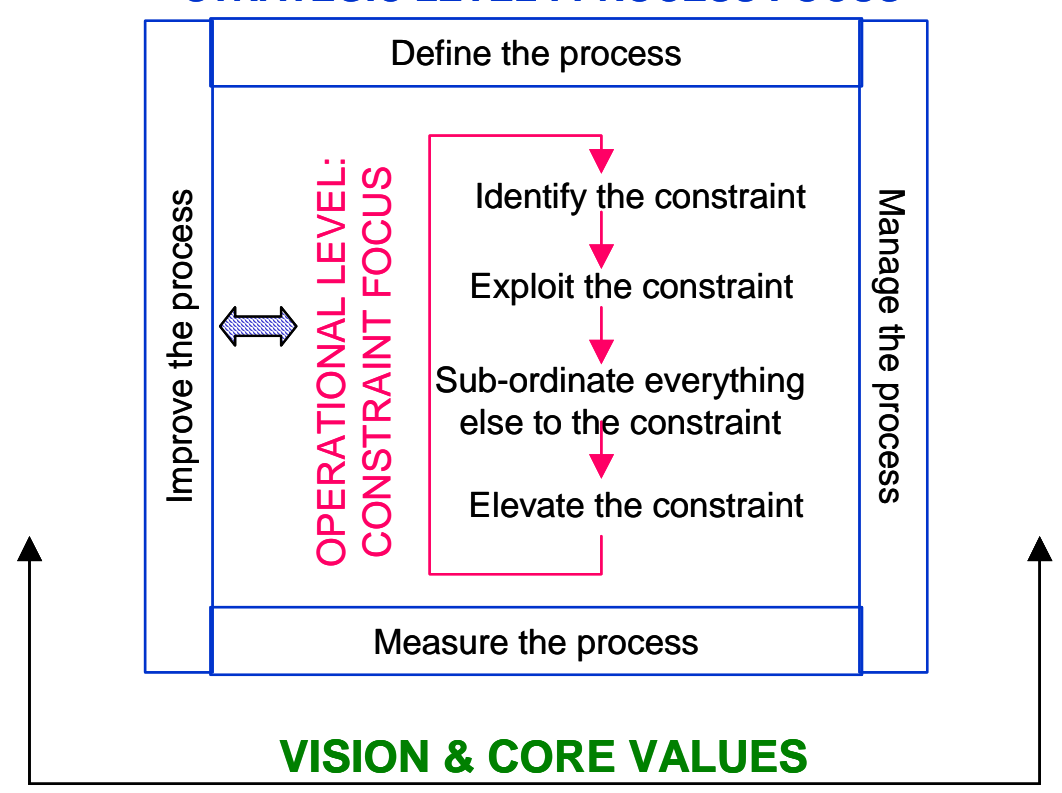

Figure 3: The mining operational management model

\subsection{Strategic level}

At this level the mining operational management model focuses on the processes within the production unit, as well as the processes that the unit interfaces with. It provides an ordered sequence of events that addresses process definition, process management and finally process improvement [element 2]. Steps 1 and 2 (define the process and manage the process) are yearly activities whereas steps 3 and 4 (measure the process and improve the process) are activities that take place continuously. Step 4 integrates with the operational cycle, as improvement opportunities that arrive from the constraint management activities within the operational cycle, utilise the same process improvement steps as described in step 4 of the strategic cycle.

\section{Step 1 - Define the process}

The first activity within step 1 is to ensure that the organisational structure of the unit is conducive to team work [element 9]. Organisational barriers (such as a split in reporting between engineering and production) may not exist. Subsequently the activities of the production unit are defined, as well as the interfaces with activities outside of the production unit [element 2]. Accountabilities for every step of the process are determined.

\section{Step 2 - Manage the process}

This step identifies the process management rules for the production unit. These rules need to be in place to ensure that decisions are taken based on fact, and according to the strategy of the mine [element 14]. As these rules are based on customer satisfaction, the first activity is to determine what the customer's requirements are. This can be achieved by answering the following questions: 
- What are the required production targets?

- What is the production schedule? (When must what quantity be produced)

- What is the allowable cost expenditure for the unit to achieve the targets?

- What are the required quality targets?

- What is the planning for the unit in terms of mine layout for the next year?

- What major initiatives are planned for the mine for the coming year?

Key Performance Indicators (KPIs) that quantify the performance of the production unit regarding quality, production and cost must also be established.

Step 3 - Measure the process

In step 2 of the strategic cycle the KPIs are determined. These KPIs must to be measured regularly (daily for the production and quality KPIs, monthly for the cost KPIs), and any deviations acted upon immediately. Various KPIs with suggested tracking tools are listed in table 6.

\begin{tabular}{|l|l|}
\hline KPI & Tool \\
\hline $\begin{array}{l}\text { Quality measurements (coal size, contamination, calorific } \\
\text { value) }\end{array}$ & Control charts [element 11] \\
\hline Production (tonnage per month/year) & Line chart [element 11] \\
\hline Downtime minutes & Scattergraph [element 11] \\
\hline Operating cost & Bar chart [element 11] \\
\hline Inventory & Spreadsheet \\
\hline
\end{tabular}

Table 6: KPIs with corresponding tracking tools

Step 4 -Improve the process

The nature of the mining operational management model implies that improvement opportunities will arise from the measurement of the KPIs, as well as from constraint management activities - a constant interaction between the strategic and operational cycles exist. To realise these improvement opportunities the following process must be followed: [element 5]

- Define the deviation

- Determine possible reasons for the deviation

- Analise each of the possible reasons to determine if occurrence of the reason could cause the deviation (From this analysis the core reason for the deviation is determined)

- Develop a solution to prevent the cause of the deviation

- Develop an implementation plan for the solution

- Implement the solution

It is important to close the strategic cycle loop by revisiting steps one to three whenever any major process change has taken place. 


\subsection{Operational level}

The first line supervisor uses the five focusing steps of constraint management to manage the operations of the unit on a day-to-day basis [elements 1 and 6]. At any point in this cycle the process improvement steps can be utilised to assist with developing solutions to identify and manage the constraint.

\section{Step 1 - Identify the constraint}

The ideal situation exists when the first operation in the production chain (the continuous miner) is the constraint. This is however not always the situation. The constraint can also be the demand for coal, or a function (equipment / process) within the production unit itself. If the constraint is within the unit, it is the function where the processing rate is equal to, or less than, the demand for coal.

To identify the constraint one or more of the following steps can be taken:

- Analyse the production rates of the equipment in the section and compare that with the demand rate

- Analyse the downtime information to determine where the major waiting time occurs.

- Execute time studies in the section

- Ask the team members which piece of equipment or part of the process is keeping them from achieving their target

- Utilise simulation software to identify the constraint

\section{Step 2 - Exploit the constraint}

When the constraint is identified, it must be utilised to the maximium. The golden rule is that every minute lost at the constraint is a minute lost to the system. Every ton of coal lost due to the constraint is a ton lost forever. There are different options available to exploit the constraint - for example: reduce set-up times, investigate hot-seat change over, doing maintenance on the constraint during off-shifts, improve the availability of the constraint etc.

\section{Step 3 -Subordinate everything else to the constraint}

The production rate of the constraint dictates the production rate of the unit. The drum-bufferrope scheduling technique needs to be utilised to schedule the production rate of all the processes in the unit [element 12].

If the continuous miner is the constraint, the scheduling is easy as the rest of the equipment can only work as fast as the feedstock tempo. If downstream equipment is the constraint, then the continuous miner's cutting tempo needs to be adjusted accordingly. If the demand rate is the constraint, the coal feeder tempo must be adjusted to the required rate.

\section{Step 4 - Elevate the constraint}

Only when the constraint is being used to full capacity, and the scheduling has been adapted to follow the tempo of the constraint, must any attempt be made to increase the capacity of the 
constraint. This can be achieved by having a standby piece of equipment available to use when the constraint is down, making sure that the right equipment is used for the different mining conditions etc.

Step 5 - Re-evaluate the system

When changes are made in the section, it creates a new set of rules, with the possibility that a new constraint may have emerged. Inertia must not be allowed to set in, and the first line supervisor needs to again start the process at step 1 of the operational cycle, "identify the constraint”. This is required whenever step 4 of the constraint management cycle is completed.

\section{CONCLUSION}

The mining operational management model provides a framework for managing the production unit on a day-to-day basis, but with a long-term vision. The model consists of a strategic and operational level. The purpose of the strategic level is to focus the unit on the requirements of the customer, and to plan for a longer time horizon. The operational level assists the first line supervisor in managing the day-to-day operations of the production unit. The model provides the tools to continuously monitor and improve the performance of the unit.

\section{REFERENCES}

[1] Mcmanus, K. 1995. Acquiring knowledge and skills for twenty-first century supervision. Management development review, vo. 8, nr. 5, p18-24.

[2] Lindbeck, A, \& Snower, D,J. 2000. Multitask learning and the reorganization of work: from tayloristic to holistic organisations. Journal of Labour Economics, July 2000, vo. 18, nr. 3, p353-367.

[3] The Antidote issue, 1997. Apply lean thinking to a value stream to create a lean enterprise, vol. 8, p11-14

[4] Bellefeuille, J. 1993. Total Quality Management. IEEE Spectrum, September 1993, p47-50

[5] Walter, G. 1986. Just -in-time methodology: Applied to document and information processing. Journal of information and image management, July 1986, p26-29.

[6] Kobayashi, i. 1994. Keys to workplace improvement. USA: Productivity Press.

[7] Zhang, Q \& Cao, M. 2002. Business process reengineering for flexibility and innovation in manufacturing. Industrial management \& data systems, vo. 102, nr. 3, p146-152.

[8] Dinesh, D \& Palmer, E. 1998. Management by objectives and the balanced scorecard: will Rome fall again?. Management Decision, vo. 36, nr. 6, p363-369.

[9] Cooke, F.L. 2000. Implementing TPM in plant maintenance: some organizational barriers. International journal of quality and reliability management, vol. 17, nr. 9, p1003-1016.

[10] Geyser, G.J. 1995. Theory of Constraints. Course material.

[11] VM SERVICES. 1992. Innovative decision thinking through value management. 